\title{
A Review: The extraction of active compound from Cymbopogon $s p$. and its potential for medicinal applications
}

\author{
${ }^{1}$ Shuhada A. Muttalib, ${ }^{1 *}$ Raihana Edros, ${ }^{2}$ Nor Azah M. A., ${ }^{1}$ Rajaletchumy V. Kutty \\ ${ }^{1}$ Faculty of Engineering Technology, Universiti Malaysia Pahang, 26300 Kuantan, Pahang, Malaysia \\ ${ }^{2}$ Natural Product Division, Forest Research InstituteMalaysia (FRIM), 52109 Kepong, Selangor, Malaysia \\ *Email : rzahirah@ump.edu.my
}

\begin{abstract}
Cymbopogon citratus and Cymbopogon nardus are plants categorized under the family of Poaceae that have been recognized with high demand in pharmaceutical industry for its wide range of pharmacological activities. The potential bioactive compounds can be obtained either through traditional or conventional methods. The plant extracts are commonly used in numbers of products for culinary, pesticides and cosmetic purposes for its flavours and fragrances. Besides, bioactive compounds extracted from both species possess good biological activities that can be applied in the pharmaceutical field.
\end{abstract}

Indexed Terms- Cymbopogon sp., Extraction, Bioactive Compounds, Biological Activities

\section{INTRODUCTION}

\subsection{Cymbopogon species}

Cymbopogon is a tall perennial grass which is natively grown in a tropical region within warm temperate [1]. This plant is originated in Asia and Australia besides being well distributed in Africa, Indian, South America, Australia, Europe and North America [1]-[3]. The genus of Cymbopogon belongs to a family known as Graminae (Poaceae) and its taxonomy position is as listed in Table 1. Generally, 55 species of Cymbopogon have been identified. There are two common species available in Malaysia which are Cymbopogon citratus and Cymbopogon nardus.

Table 1: The taxonomic position of Cymbopogon $s p$.

\begin{tabular}{cc}
\hline KINGDOM & PLANTAE \\
\hline Sub-Kingdom & Tracheobionta \\
Superdivision & Spermatophyta \\
Division & Magnoliophyta \\
Class & Liliopsida \\
Sub-class & Commelinidae \\
Order & Cyperales \\
Family & Poaceae \\
Genus & Cymbopogon \\
\hline
\end{tabular}


C. citratus (DC.) Stapf is well-known as a lemongrass and it is typically identified as West Indian lemongrass [1], [4]-[7]. West Indian lemongrass is believed to have originated either in Malaysia or in Sri Lanka. Then, it is widely distributed and grown in India, Thailand, Bangladesh, Madagascar and China, America and Africa [3], [4], [8], [9]. In contrast, C. nardus is known as Citronella. C. nardus (L) Rendle is classified in cultivated types named as Ceylon Citronella [1], [4], [5]. This plant has probably originated from Sri Lanka and then introduced in Java around 1899 [1], [10]-[12]. Subsequently, Java becomes a major producer of citronella in the world. Furthermore, C. nardus is also growing wild in most tropical Asian countries including Malaysia.

\subsection{Cultivation, harvesting and the processing of Cymbopogon sp.}

Cymbopogon $s p$. has been commonly cultivated as a ratoon crop and well grown in a wide range of soils and climatic conditions [1]. For example, $C$. citratus and $C$. nardus have vigorous growth conditions in both tropical and subtropical climate [1], [5]. Meanwhile, the optimum growths of both sp. are warm and humid climate. Both plants require direct exposure to sunlight and an average rainfall per annum needed is in between 250 to $330 \mathrm{~cm}$ [5], [7]. The temperature that is suitable for growth is ranging in between 20 to $30^{\circ} \mathrm{C}$. C. citratus is flourished in well-drained sandy loam which is from rich loam to poor laterite [1], [4]-[7]. Similar to C. nardus where it is well planted on most soil types ranging from sandy, mineral to organic soils [5], [13]. Hence, this plant also grows abundantly in most places including mountain and hillside area [1]. The optimum of growth conditions had resulted specific morphological features for each species. Both of the species are classified as an aromatic tall grass, growing to approximately $1 \mathrm{~m}$ in height with long and thin leaves [5], [12]-[15]. However, some of the features for both sp. are different. $C$. citratus have short stems and fibrous roots meanwhile its leaves are narrow and linear. In contrast, $C$. nardus has whitish stems and sometimes with magentatinged while the leaves are smaller with rough surface [1].

C. citratus is first harvested in the range of four to six months upon plantation followed by subsequent harvests in the interval of two to three months [4], [16]. Likewise, C. nardus is ready for harvest after six to eight months of planting but the subsequent harvesting can be done within 90 to 120 days [14], [17], [18]. Nevertheless, the numbers of harvest for both species are subject to the growth of plants.

The lemongrass can be divided into several parts including leaves, aerials and rhizomes [2], [5], [19]-[21]. These parts are subjected to a drying process in which dried material is prepared for further processing because it reduces the moisture content of fresh materials for long storage. Besides, drying process capable to preserve the sample from further deterioration by microorganisms and preserve its biochemical constituents. In dry part there is no further enzymatic or metabolic reaction of dried plants and all compounds can be recovered in a natural without altered form [22]-[25]. However chloroplast and active metabolic are presence in fresh green leaves of Cymbopogon sp. besides remains a possibility of formation of new compounds such as intermediates and secondary metabolites [26]. There are two common methods used in the drying process of Cymbopogon plants which are sun drying, air drying and oven drying [10], [22]-[31]. The chemical composition of Cymbopogon extracts are influence by a variety of drying methods. For example, the crude essential oil extracted from $C$. citratus are resulted highest percentage yield (2.45\%) using oven drying compared to air drying (2.12\%) and sun drying methods (2.10\%) [30]. Meanwhile, C. nardus dried using oven drying methods obtained $9.40 \%$ of percentage yield of crude essential oil [30]. The dried herbs are then ground into small pieces typical in the size of $0.3 \mathrm{~mm}$ to $2.0 \mathrm{~mm}$. Traditionally the grinding process is performed in various ways such as using mortar and pestle, crushing, blending and grinding [31], [32]. The extraction process usually take parts after raw material already dried and reduce in particle size. There are two common approaches in the extraction process, firstly through a traditional approach, secondly through a conventional approach [10], [29]-[34]. 


\section{EXTRACTION PROCESS}

\subsection{Extraction methods for traditional processes}

Decoction and infusion are common classical methods involve in extraction process [2], [35]-[36]. Basically, during the decoction process, stable constituents of a crude drug will be extracted in hot water soluble [37]. This process will be subject to boiling in water for 15 minutes, cooling, and straining before passing the sufficient cold water which contains a liquid extract [37]. In contrast with infusion methods where soluble components extract from the plants were immersed in hot water without continuous boiling [2], [3], [35], [38]. The solution will be cooling before straining [2], [35], [39]. This method normally applied in lemongrass tea processing where lemongrass is immersed in hot water [5], [39]-[42]. It is mostly taken in the form of tea as a remedy for a cough, flu, headache, pneumonia, malaria, digestive problems, diarrhea, stomach ache and vascular disorders [5], [27], [39][42], [27]. However, traditional process is difficult to optimize due to inaccurate of dosage extract. Hence, boiling sample at boiling point of water is able to reduce the amount of plant extract. Therefor the efficacy of herbal extract as alternative medicine also reduce.

\subsection{Extraction method for conventional processes}

Current practices involve the use of general methods of extraction that have been well developed due to the application of advanced technology. These extraction methods are known as Soxhlet extraction [43]-[45], microwave-assisted extraction [22], [44]-[50], ultrasound extraction [33], [34], [51], supercritical fluid extraction [11], [20], [27], [52], [53], hydrodistillation [22], [24], [44], [49], [54], [55] and steam distillation [14], [52], [56]-[62], [63], [64]. Each process is unique in terms of the process principal and process parameters, however the selection basis is generally depending on the yield of the process [52], [59], [65]. Hence, conventional extraction methods have many advantages where the process is flexible, allows modulation selection of solvent extract besides polluting organic solvent can be eliminated during the extraction process. Hence, the amount of plant extract can be optimized. For example, the yield of essential oil extracted using distillation process can be optimize either increase the raw material use or prolong the extraction time. Figure 1 shows the simple process flow of steam distillation process including the sample preparation, pretreatment process and extraction process. 


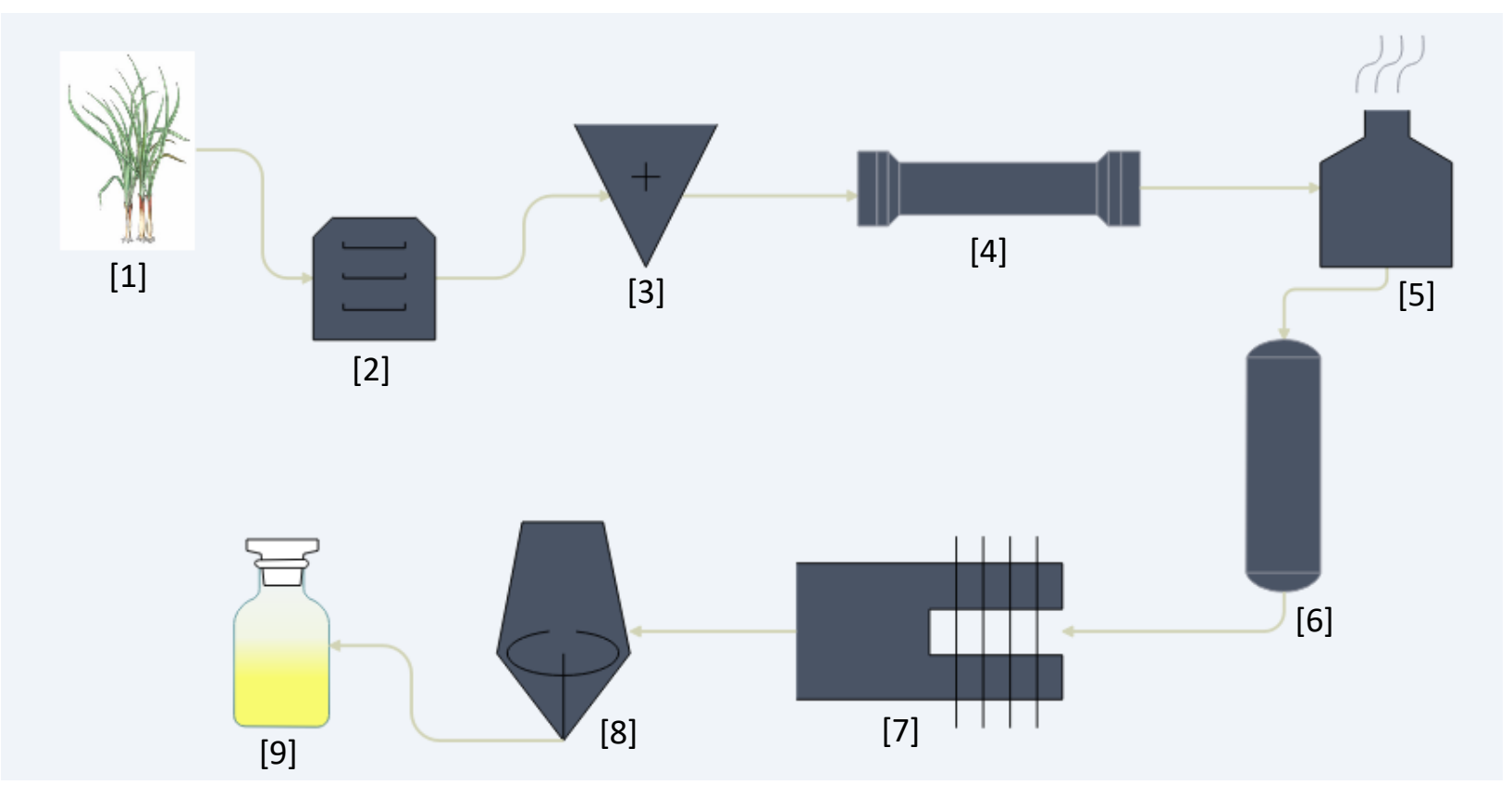

Figure 1: Simple flow diagram of steam distillation process to extract lemongrass oil; [1] Raw material collection [2] Drying process [3] Grinding process [4] Pretreatment process [5] Boiling process to generate steam [6] Oil extract using steam distillation process [7] Condensation process [8] Plant extract collection [9] Lemongrass oil is produced

\subsection{The plant extract}

The extracts from Cymbopogon normally exist in several forms, liquid [36], [39] and oil [4], [10], [16], [22]-[28], [33], [34]. The oil-based extract is normally known as essential oil and this product has been widely used as insect repellent to kill the Aedes mosquitoes [5], [26], [31], [32], [37], [40], [51] alternative medicines [2], [35], [59], [66] aromatherapy and cosmetic [2], [10], [27], [33]- [35], [39], [67]-[69]. Due to its nice odour, Cymbopogon $s p$. is widely used as a flavouring ingredient in number of products such as soaps, perfume, candle and insects repellent [69]. In spite of, the liquid extract of Cymbopogon sp. traditionally used to produce an aromatic drink by incorporated the whole plant in a water whereas the stems often used in cooking. The essential oil that is obtained from plants extracts is formerly known as crude essential oil. The extracts are relatively a complex mixture of metabolites presence in liquid form intended for oral and external uses [20], [43], [44], [62], [66]. During the extraction, solvents diffuse into the solid plant material and solubilize the compounds with similar polarity [33], [34], [67], [68], [70], [71].

The quality of the plant extract can be influenced by several factors including the plant part used as raw material to extract, choice of solvent used during the extraction process and the procedure of extraction [33], [34], [70], [71]. The phytochemical constituents of Cymbopogon sp. extracts are varying according to extraction time, temperature and concentration used, selection of extraction method, part of the plant used, the polarity of solvent used, geographical of plant origin and harvesting period. Despite the quality, the yield of crude essential oil is one of the important parameters. The yield can be identified according to the relation between the essential oil mass obtained and the raw material used in the extraction. The summary of percentage yield is calculated using the formula as follow:

$$
\text { Percentage of yield }(\%)=\frac{Y_{i}}{Y_{0}} \times 100 \%
$$


where;

Yi $\quad=$ Actual mass

Yo $\quad=$ Calculated mass

Basically, the average oil content is about $1 \%$ on the basis of fresh leaves within 2 to 3 hours of distillation [5], [57], [58]. The oil extracted from Cymbopogon sp. consists higher of volatile compounds. The determination of bioactive compounds obtained from plant extract is largely dependent on the type of solvent used during the extraction. The selection of solvent used during extraction is dependent on some factors such as toxicity level, the ability of solvent to evaporate at low heat, inability to produce a complex extract, a rapid absorption of the extract, and good as preservative action. [33], [34], [70]. For example, water is universal solvent and widely use in plant extraction for some purpose such as antimicrobial activity. Water is non-toxic and able to reduce the health hazards potential of the extractants.

The bioactive compounds extractive from lemongrass oil is useful in some health concern. In order to obtain the valuable aromatic compound, essential oil is necessary to extract from the plant herbs. Besides, the different method extraction will provide vary optimum condition to extract maximum crude essential oil [14], [17]. Hence, the chemical constituents and yield obtained will vary due to several factors such as time extraction, method extraction and also raw material preparation. The active compound extracted from lemongrass oil can be identified using Gas Chromatography Mass Spectrometry (GCMS).

\section{CHEMICAL ANALYSIS}

\subsection{Gas Chromatography}

The aromatic compound of essential oils is generally performed quantitatively and qualitatively by Gas Chromatography (GC) and Gas Chromatography Mass Spectrometry (GCMS) [20], [60]. Gas Chromatography is used to identify a volatile compounds using gas phase. In gas chromatography, the mobile phase known as carrier gas, usually used as inert gas such as helium and nitrogen. The stationary phase is a polymer or liquid microscopic layer on an inert solid support located inside a column. As a result, the compound in gas phase subject to total amount of vapour. Retention times and Kovats index were used to compare the percentage of main compounds using a mass spectrometry detector [4], [16]. Besides, good chromatogram can be obtained by consider numerous conditions during the process of analysis using GC and GCMS which including the sample preparation, column type and dimensions size, carrier gas flow rate during the analysis process and temperature programming including injector, detector and column temperature [72]. On the other hand, the molecules structurally similar like stereo-isomeric compounds of essential oils which are difficult to separate by GC instruments can be analyzed by 13C NMR [73]. Therefore, this technique is also applied to identify the quality control of volatile compounds of essential oils. Mass Spectrometry is normally used to identify and elucidate the structure and chemical properties of molecules include

unknown compounds. Besides, the MS Spectrum able to determine the molecular weight of the sample. 


\subsection{Infrared Spectroscopy}

Infrared Spectroscopy is used to determine the functional group present in the sample. This instrument able to measure the wavelength and intensity of the absorption of mid-infrared light by a sample [70]. IR spectroscopy also used to confirm the identity of a particular compound beside capable to determine the newly synthesized molecule. The IR wavelength shows the characteristics of specific types of chemical bonds. An addition, IR spectroscopy is useful for qualitative analysis of organic and organometallic molecules. For example, citral is major compound in C. citratus extract. In the IR spectrum analysis, the functional groups of citral were observed. In the vibrations at $2968 \mathrm{~cm}^{-1}$, asymmetric stretching of - $\mathrm{CH} 3$ is observed corresponding to an alkyl saturated aliphatic group and at 2915 and $2857 \mathrm{~cm}^{-1}$ [29]. At $1671 \mathrm{~cm}^{-1}$ of intense band is observed due to vibrations of $\mathrm{C}=\mathrm{C}$ (cis and trans). The presence double bonds $(\mathrm{C}=\mathrm{C}-\mathrm{CHO})$ in citral showed as acyclic monoterpenes. The list of detector used in each instrument for qualitative and quantitative analysis are summarized in Table 2.

Table 2: Qualitative and quantitative analysis involves in the identification of Cymbopogon extract

\begin{tabular}{|c|c|c|c|}
\hline $\begin{array}{c}\text { INSTRUMENT } \\
\text { USE }\end{array}$ & $\begin{array}{c}\text { DETECTOR USE } \\
\text { IN INSTRUMENT }\end{array}$ & $\begin{array}{l}\text { PURPOSE OF } \\
\text { DETECTION }\end{array}$ & REFERENCES \\
\hline $\begin{array}{c}\text { Fourier Transform } \\
\text { Infrared Spectroscopy } \\
\text { (FTIR) }\end{array}$ & $\begin{array}{c}\text { Infrared } \\
\text { Spectroscopy (IR) }\end{array}$ & $\begin{array}{l}\text { To identify the functional groups } \\
\text { present in the active compounds }\end{array}$ & [70] \\
\hline $\begin{array}{c}\text { Gas Chromatography } \\
\text { (GC) }\end{array}$ & $\begin{array}{l}\text { Mass Spectrometry } \\
\text { (MS) } \\
\text { Flame Ionization } \\
\text { Detector (FID) }\end{array}$ & $\begin{array}{l}\text { To determine the molecular } \\
\text { weight of the volatile compound } \\
\text { To measure the essential oil } \\
\text { concentration using a gas stream }\end{array}$ & $\begin{array}{c}{[1],[4],[16],} \\
{[22]-[25],[70],} \\
{[72],[73]}\end{array}$ \\
\hline $\begin{array}{c}\text { Nuclear Magnetic } \\
\text { Resonance } \\
\text { Spectroscopy (NMR) }\end{array}$ & $\begin{array}{c}{ }^{13} \mathrm{C}-\mathrm{NMR} \text { and }{ }^{1} \mathrm{H}- \\
\text { NMR }\end{array}$ & $\begin{array}{l}\text { To identify carbon atoms and } \\
\text { hydrogen atoms that present in the } \\
\text { single compound }\end{array}$ & {$[33],[34],[70]$} \\
\hline
\end{tabular}

\section{A POTENTIAL BIOACTIVE COMPOUNDS}

\subsection{Phytochemical constituents of Cymbopogon extract}

The Cymbopogon extract contains some chemical substances that produce physiological and biochemical actions in the human body. Most of the bioactive constituents attributed to Cymbopogon extract are derived from its leaves, stem, and rhizomes, and their secondary metabolites. Despite these differences, a number of classes of compounds are reproducibly found, including phytonutrients, mineral contents and essential oils. The list of phytonutrients exists in Cymbopogon sp. are shown in Table 3 such as tannins, phenolics, saponins, flavonoids, steroids, carbohydrates, glycosides, protein and amino acid. The class of aromatic compound is tabulated in Table 4 meanwhile Table 5 had shown that numerous mineral contents appear in Cymbopogon extract [2], [39], [35], [71]. Despite these differences, the crude of essential oil extract from Cymbopogon plant consists a number of classes volatile compounds such as hydrocarbon terpenes, alcohols, ketones, esters and mainly aldehydes. The molecular structure of some active compounds namely as Linalool (1), Geraniol (2), Nerol (3), Geranial (4), Myrcene (5), Citronellal (6), Neral (7), Citronellol (8), Limonene (9), Elemol (10) are shown in Figure 2. 
Table 3: Phytonutrients reported in Cymbopogon sp.

\begin{tabular}{clcl}
\hline GROUP OF & \multicolumn{1}{c}{ BIOACTIVE } & NAME OF & \multicolumn{1}{c}{ REFERENCES } \\
PYTOCHEMICALS & \multicolumn{1}{c}{ COMPOUNDS } & METHOD USE & \\
\hline Terpenoids and & Ketones, aldehyde, & Distillation & {$[1],[2],[5],[10],[14]-[18]$,} \\
essential oils & $\begin{array}{l}\text { alcohol groups, } \\
\text { hydrocarbon, terpenes, } \\
\text { esters }\end{array}$ & method & {$[27],[28],[33]-[39],[52]$,} \\
& & {$[57],[58],[63],[64],[67],[70]$} \\
\hline
\end{tabular}

Table 4: Essential oil of Cymbopogon extract contains a numerous aromatic compound

\begin{tabular}{|c|c|c|c|}
\hline $\begin{array}{c}\text { GROUP OF } \\
\text { PHYTO- } \\
\text { CHEMICALS }\end{array}$ & $\begin{array}{c}\text { BIOACTIVE } \\
\text { COMPOUNDS }\end{array}$ & $\begin{array}{l}\text { NAME OF } \\
\text { TEST USE }\end{array}$ & REFERENCES \\
\hline $\begin{array}{l}\text { Mineral } \\
\text { contents }\end{array}$ & $\begin{array}{l}\text { Sodium }(\mathrm{Na}) \\
\text { Calcium }(\mathrm{Ca}) \\
\text { Iron }(\mathrm{Fe}) \\
\text { Phosphorus }(\mathrm{P}) \\
\text { Potassium }(\mathrm{K}) \\
\text { Magnesium }(\mathrm{Mg}) \\
\text { Zinc }(\mathrm{Zn})\end{array}$ & $\begin{array}{l}\text { Qualitative and quantitative } \\
\text { using: } \\
\text { - Instrumental Neutron } \\
\text { Activation Analysis } \\
\text { - Atomic Absorption } \\
\text { Spectrophotometer }\end{array}$ & $\begin{array}{l}{[33],[34],[39],} \\
{[67],[68],[71]}\end{array}$ \\
\hline
\end{tabular}

Table 5: Mineral content reported in Cymbopogon sp.

\begin{tabular}{|c|c|c|c|c|}
\hline $\begin{array}{l}\text { GROUP OF } \\
\text { PHYTO- } \\
\text { CHEMICALS }\end{array}$ & $\begin{array}{l}\text { BIOACTIVE } \\
\text { COMPOUNDS }\end{array}$ & $\begin{array}{l}\text { STRUCTURAL } \\
\text { FEATURES }\end{array}$ & $\begin{array}{l}\text { NAME OF } \\
\text { TEST USE }\end{array}$ & REFERENCES \\
\hline \multirow[t]{8}{*}{ Phytonutrients } & Phenolics & $\begin{array}{l}\text { C3 side chain, -OH groups, } \\
\text { phenol ring }\end{array}$ & $\begin{array}{l}\text { Lead acetate } \\
\text { test, }\end{array}$ & \multirow{8}{*}{$\begin{array}{c}{[2],[5],[10],} \\
{[27],[28],} \\
{[35],[40][42],} \\
{[66]-[68],} \\
{[71],[74]}\end{array}$} \\
\hline & Tannins & $\begin{array}{l}\text { Polymeric phenols (molecular } \\
\text { weight: } 500-3000 \text { ) }\end{array}$ & $\begin{array}{l}\text { Ferric chloride } \\
\text { test }\end{array}$ & \\
\hline & Flavanoids & $\begin{array}{l}\text { Phenolic structure, one } \\
\text { carbonyl group, hydroxylated } \\
\text { phenols, 3-hydroxyl group }\end{array}$ & Lead acetate test & \\
\hline & Steroids & $\begin{array}{l}\text { Organic compound with } 4 \\
\text { rings }\end{array}$ & Salkowski test & \\
\hline & Saponins & Amphipathic glycosides & $\begin{array}{l}\text { Honeycomb test, } \\
\text { Foam test }\end{array}$ & \\
\hline & Carbohydrates & $\begin{array}{l}\text { Biological molecule form of } \\
\text { monosaccharides consists of } \\
\mathrm{H}, \mathrm{C} \text {, and } \mathrm{O} \text { atom }\end{array}$ & $\begin{array}{l}\text { Fehlings test, } \\
\text { Benedicts test }\end{array}$ & \\
\hline & Glycosides & $\begin{array}{l}\text { Sugar with non-carbohydrate } \\
\text { moiety }\end{array}$ & Glycosides test & \\
\hline & $\begin{array}{l}\text { Protein and } \\
\text { amino acids }\end{array}$ & $\begin{array}{l}\text { Linked together through } \\
\text { peptides bonds and cross- } \\
\text { linked chains by hydrogen } \\
\text { bonds }\end{array}$ & $\begin{array}{l}\text { Biuret test, } \\
\text { Kjedahl method, } \\
\text { Ninhydrin test }\end{array}$ & \\
\hline
\end{tabular}


The phytochemicals that present in Cymbopogon extract is presented in Table 6. The constituents of essential oil extracted from $C$. citratus and $C$. nardus using different extraction method were analyzed by GCMS and summarize in Table 7 [10], [14], [17], [22]-[28], [63], [64]. Several research works have been reported that the chemical composition of the essential oil of $C$. citratus and $C$. nardus varies according to the geographical origin [63], [64]. In addition, the different percentage of essential oil composition is might be affected by several factors such as climate, the age of plantation and efficiency of distillation method [10], [27], [28]. For example, $C$. citratus contains a high percentage of citral, which is a mixture of terpenoids neral and geranial [16], [75]. Besides, this high citral content justifies the large scale commercial cultivation of $C$. citratus in several countries and it is responsible for the lemony odor and serves as an aroma compound and used in perfumery. However, the younger C. nardus leaves were found to have a higher content of citronellal and citronellol while the older leaves were found to have a higher content in geraniol. As mentioned earlier, the Cymbopogon sp. has lemony scent ordour due to citral was found in high percentage in the older $C$. nardus leaves. This could be the main compound that contributed to the differences in smell and appearance of Cymbopogon extract. Citral extracted from Cymbopogon $s p$. are valuable for pharmacology activities such as antimicrobial activity, antimutagenicity effect, antioxidants, hypocholesterolemic, and antinociceptive effects.

Table 6: Potential active compounds reported in lemongrass oil and citronella oil

\begin{tabular}{|c|c|c|}
\hline \multicolumn{2}{|c|}{ PLANT TYPE } & ACTIVE COMPOUND \\
\hline Cymbopogon ci & tus [2], [35] & $\begin{array}{l}\text { citral, } \alpha \text {-terpinol, } \beta \text { - } O \text {-cimene, } \alpha \text {-pinene oxide, } t \text {-muurolol, } \\
1 \text {-Octyn-3-ol, neral, geranial, citronellol, } \gamma \text {-muurolene, } \alpha \text {-farnesene, } \\
\delta \text {-cadinene, } \beta \text {-myrcene, linalool, citronellal, nerol, geranyl-acetate, } \\
t \text {-cadinol }\end{array}$ \\
\hline $\begin{array}{l}\text { Cymbopogon } \\
\text { nardus } \\
{[10],[27],[28]}\end{array}$ & Ceylon type & $\begin{array}{l}\text { Camphene, dipentene, citronellal, geraniol, geranyl acetate, nerol, } \\
\text { citronellol, farnesol, linalool, borneol and methyl eugenol } \\
\text { Limonene, citronellal, citral, geraniol, citronellol, citronellal, } \\
\text { eugenol, chavicol, elemol, citronellyl oxide, } \delta \text {-cadinene, } \gamma- \\
\text { cadinene, methyl eugenol, and vanillin }\end{array}$ \\
\hline
\end{tabular}


Table 7: The chemical compositions of oil extracted from Cymbopogon citratus and Cymbopogon nardus using various method of distillation and analyze by GCMS

\begin{tabular}{|c|c|c|c|c|c|c|c|c|c|}
\hline \multirow{2}{*}{$\begin{array}{l}\text { Method Use } \\
\text { Plant Species }\end{array}$} & \multicolumn{2}{|c|}{$\begin{array}{c}\text { Steam } \\
\text { Distillation }\end{array}$} & $\begin{array}{c}\text { Microwave } \\
\text { Hydro - }\end{array}$ & \multicolumn{2}{|c|}{$\begin{array}{c}\text { Hydro- } \\
\text { distillation }\end{array}$} & $\begin{array}{c}\text { Steam } \\
\text { Distillation }\end{array}$ & \multicolumn{2}{|c|}{$\begin{array}{c}\text { Unknown } \\
\text { Method }\end{array}$} & \multirow[t]{2}{*}{$\begin{array}{c}\text { Hydro- } \\
\text { distillation }\end{array}$} \\
\hline & \multicolumn{5}{|c|}{ Cymbopogon citratus } & \multicolumn{3}{|c|}{ Cуmbopogon nardus } & \\
\hline Plant Origin (Variety) & Unknown & Unknown & Malaysia & Malaysia & Malaysia & $\begin{array}{c}\text { Malaysia } \\
\text { (Ceylon) }\end{array}$ & $\begin{array}{c}\text { India } \\
\text { (Java) }\end{array}$ & $\begin{array}{c}\text { India } \\
\text { (Ceylon) }\end{array}$ & $\begin{array}{c}\text { Malaysia } \\
\text { (Ceylon) }\end{array}$ \\
\hline $\begin{array}{l}\text { Compound } \\
(\% \text { of mass })\end{array}$ & {$[57],[58]$} & {$[52]$} & [24] & [24] & [64] & {$[14],[18]$} & [27] & {$[27]$} & {$[14]$} \\
\hline$\beta$-mycrene & 6.80 & 10.20 & 3.96 & 9.91 & 2.09 & - & - & 0.30 & - \\
\hline Linalool & - & 0.58 & 0.48 & - & 1.37 & - & 1.50 & 1.20 & - \\
\hline Citrnonellal & 35.90 & 0.20 & - & - & 0.33 & 20.99 & 32.70 & 5.20 & 22.09 \\
\hline Citronellol & 5.20 & - & 0.50 & - & - & 13.64 & 15.90 & 8.40 & 12.26 \\
\hline Nerol & - & 32.40 & - & - & 5.49 & - & 7.70 & 0.90 & - \\
\hline Neral & - & - & 35.69 & 9.91 & - & 4.94 & - & - & 7.97 \\
\hline$\beta$-citral & - & - & - & - & 23.77 & - & - & - & - \\
\hline geraniol & 20.90 & 5.50 & - & - & 12.05 & 42.43 & 23.90 & 18.00 & 41.48 \\
\hline geranial & 1.50 & 45.20 & 50.81 & 49.46 & 32.43 & 4.39 & - & - & 8.39 \\
\hline$\delta$-cadinene & 2.10 & 0.95 & - & - & 0.24 & 1.35 & - & - & - \\
\hline elemol & - & 0.60 & - & - & 0.17 & - & 6.00 & 1.70 & - \\
\hline caryophyllene oxide & - & 0.18 & - & - & 0.46 & - & - & - & - \\
\hline$\alpha$-gurjene & - & 0.45 & - & - & 1.76 & - & - & - & - \\
\hline$\delta$-limonene & 1.80 & - & - & - & - & - & 1.30 & 9.70 & - \\
\hline citronellyl acetate & 2.90 & - & - & - & - & 2.13 & 3.00 & 1.90 & 1.37 \\
\hline geranyl acetate & 4.00 & - & - & - & - & 7.74 & - & - & 4.73 \\
\hline
\end{tabular}


<smiles>C=CC(C)(O)CCC=C(C)C</smiles>

[1]<smiles>C=CC(=C)CCC=C(C)C</smiles>

[5]<smiles>C=C(C)C1CC=C(C)CC1</smiles>

[9]<smiles>CC(C)=CCCC(C)C(C)CO</smiles>

[2]<smiles>CC(C)CCCC(C)C=O</smiles>

[6]<smiles>CC(C)=CCC/C(C)=C\CO</smiles>

[3]<smiles>CC(=CC=O)CCCC(C)C</smiles>

[7]<smiles>CC(C)=CCC/C(C)=C/C=O</smiles>

[4]<smiles>CC(C)=CCCC(C)CCO</smiles>

[8]<smiles>C=CC1(C)CCC(C(C)(C)O)CC1C(=C)C</smiles>

[10]

Figure 2: Molecular structure of aromatic compound extract from Cymbopogon plant 


\section{BIOLOGICAL ACTIVITIES}

\subsection{Biological activities of $C$. citratus and C. nardus}

The Cymbopogon extract is good as traditional herbal remedies and have the ability to treat several diseases such as gastrointestinal problems, fever and hypertension [2], [5], [76]. For example, the product extract of $C$. citratus is known as a folk remedy for such treatment such as a cough, consumption, flu, headache, pneumonia, malaria, digestive problems, diarrhea, stomach ache and vascular disorders [2], [3], [5], [76]. It is mostly taken in the form of tea as a remedy. Other than that, C. citratus has been widely used as carminative and insect repellent besides contributes good scent flavour in the culinary process for food preparation. C. nardus extract has similar application and traditionally used for postpartum bath. This plant will be boiled and used externally during the shower for confinement lady. In addition, $C$. nardus extracts is well used as body massage at body spa center. Meanwhile, in Chinese culture, the leaves of $C$. nardus specifically use for rheumatism and commonly uses in the treatment of fever, digestive problem, intestinal parasites, and menstrual problems.

It has been documented in various literature that the active compound obtained from both of $C$. citratus and $C$. nardus possess several biological activities, such as antimicrobial activity, antimutagenicity effect, anti-inflammatory effect, anti-nociceptive effect, hypocholesterolemic effect and antioxidant [1], [4], [77]. A number of studies have found that $C$. citratus extract able to exhibit inhibition against several isolates bacterial such as Staphylococcus aureus, Streptococcus bovies, Salmonella typhi and Escherichia coli [78]. The active compound of $C$. citratus was extracted using the different type of solvent which are methanol and aqueous extract. The results obtained showed that microbial growth was greater in methanol extract as compared to aqueous extract [78]. Furthermore, the essential oil that has been extracted from $C$. nardus has high potential to function as antibiotic for the use against systemic bacteria which have been isolated from the internal organs of aquatic animals [62]. Minimum inhibitory concentration (MIC) of the essential oil tested against bacteria isolated from these aquatic animals were determined by using two-fold broth microdilution method with kanamycin and eugenol as positive controls [62], [79]. The MIC values of the citronella against isolated bacterial such as Edwardsiella spp. $(\mathrm{n}=21)$, Vibrio spp. $(\mathrm{n}=6)$, Aeromonas spp. $(\mathrm{n}=2)$, Escherichia coli $(\mathrm{n}=2)$, Salmonella spp. $(\mathrm{n}=2)$, Flavobacterium spp. $(\mathrm{n}=1)$, Pseudomonas spp. $(\mathrm{n}=1)$ and Streptococcus spp. $(\mathrm{n}=1)$ ranged from 0.244 $\mu \mathrm{g} / \mathrm{ml}$ to $0.977 \mu \mathrm{g} / \mathrm{ml}[62]$.

Also, the chemical constituents of $C$. nardus demonstrated strong antimutagenic effect towards $S$. typhimurium strains TA98 and TA100 [80], [81]. Results obtained from mutagenic testing evaluate that ethanol and water extract of $C$. nardus extracted were not mutagenic to both strains of $S$. typhimurium [80]. In particular, methanolic extracts of $C$. citratus such as alkaloids, steroids, flavonoids, tannins, saponins and carbohydrates possess moderate analgesic activity as well as exhibited significant anticancerous activity [5], [82]. In addition, an aqueous root extract of $C$. citratus possesses to treat anxiety disorders at different dose levels in comparison to standard and normal saline group. Essential oils obtained from Cymbopogon extract have folk medicine properties due to the presence of citral compound. Citral compound has a significant pharmacological evidence as antidiabetic by reducing the effect of Type 2 diabetes with multiple targets in Wistar rats [4], [83], [84]. In other investigation, highest dosage of lemongrass oil has indicated a useful effect of reducing the cholesterol level in the blood [4], [85]. In addition, inhalation of citronellol compound presence in citronella oil has an indirect role to promote weight loss by reducing the appetite for food intake without affecting the liver [85].

The main aromatic compound possesses high biological activity had summarized in Table 8 . Although a lot of pharmacological investigations have been carried out based on the ingredients present, a lot more can still be explored, exploited and utilized. 
Table 8: Biological properties of Cymbopogon sp.

\begin{tabular}{clc}
\hline Component & \multicolumn{1}{c}{ Biological activities } & References \\
\hline mycrene & Antibacterial activity & {$[2],[27],[33],[35],[59]$,} \\
citral & Antibacterial activity & {$[68],[75],[86]$} \\
$\alpha$-citral (geranial) & Antinociceptive activities & {$[59],[66],[75],[86],[87]$,} \\
& Antimicrobial activity & {$[88]$} \\
$\beta$-ciral (neral) & Antinociceptive & {$[65]$} \\
geraniol & Antiviral activity & {$[66],[88]$} \\
limonene & Antioxidant activity & {$[5],[8],[22]-[25],[33]$,} \\
& & {$[34],[41],[42],[71]$} \\
methyl heptenone & Anti-diabetic activity & {$[5],[15],[57],[58],[65]$,} \\
& Anxiolytic properties & {$[77],[79]$} \\
& Antinociceptive activity & \\
& Antifungal activity & {$[2],[10],[38],[75],[90]$} \\
\hline
\end{tabular}

\section{CONCLUSION}

It can be concluded that liquid and oil extract for both Cymbopogon sp. have therapeutic constituents and widely used in numerous industry includes agriculture, medicinal and perfumery industries. The conventional methods of extraction process are widely used such as by distillation process to produce a good yield of lemongrass oil extract. The choice of solvent will be influence the result of product extract. Water is the best solvent extract to lower the toxic effect. Gas Chromatography with Mass Spectrometry detector is practical quantitatively and qualitatively in order to identified the chemical constituents of volatile compound in essential oil. Most of the compounds reported in Cymbopogon extract are neral, geranial, geraniol, citral, citronellal, citronellol and mycrene. This mainly aromatic compound is reported to be high potential to treat a numerous disease and proven by a variety of biological activities.

\section{REFERENCES}

[1] A. Akhila, Essential Oil-Bearing Grasses: The genus Cymbopogon Medicinal and Aromatic Plants - Industrial Profiles. 2010.

[2] C. E. Ekpenyong, E. Akpan, and A. Nyoh, "Ethnopharmacology, phytochemistry, and biological activities of Cymbopogon citratus (DC.) Stapf extracts," Chinese Journal of Natural Medicines, vol. 13, no. 5. pp. 321-337, 2015.

[3] O. Avoseh, O. Oyedeji, P. Rungqu, B. Nkeh-Chungag, and A. Oyedeji, "Cymbopogon species; ethnopharmacology, phytochemistry and the pharmacological importance," Molecules, vol. 20, no. 5. pp. 7438-7453, 2015.

[4] K. Manvitha and B. Bidya, "Review on pharmacological activity of Cymbopogon citratus," Int. J. Herb. Med., vol. 1, no. 6, pp. 5-7, 2014.

[5] J. S. Raut and S. M. Karuppayil, "A status review on the medicinal properties of essential oils," Ind. Crops Prod., vol. 62, pp. 250-264, 2014.

[6] A. K. Yadava, "Cultivation of lemon grass (Cymbopogon flexuosus, 'CKP-25') under poplar based agroforestry system," Indian For., vol. 127, no. 2, pp. 213-223, 2001.

[7] J. C. a González, N. G. De Colmenares, a Usubillaga, E. Darghan, and S. Linares, "Evaluation of agronomical variables in the cultivation of lemon grass (Cymbopogon citratus II Stapf) for the production of essential oil," Evaluación Var. agronómicas en el Cultiv. limonaria (Cymbopogon citratus Stapf) para la Prod. aceite Esenc., vol. 33, pp. 693-699, 2008.

[8] G. Shah, R. Shri, V. Panchal, N. Sharma, B. Singh, and a. S. Mann, "Scientific basis for the 
therapeutic use of Cymbopogon citratus, stapf (Lemon grass).," J. Adv. Pharm. Technol. Res., vol. 2, no. 1, pp. 3-8, 2011.

[9] K. Manvitha and B. Bidya, "Review on pharmacological activity of Cymbopogon citratus," Int. J. Herb. Med., vol. 1, no. 6, pp. 5-7, 2014.

[10] A. Wany, A. Kumar, S. Nallapeta, S. Jha, V. K. Nigam, and D. M. Pandey, "Extraction and characterization of essential oil components based on geraniol and citronellol from Java citronella (Cymbopogon winterianus Jowitt)," Plant Growth Regul., vol. 73, no. 2, pp. 133-145, 2014.

[11] C. F. Silva, F. C. Moura, M. F. Mendes, and F. L. P. Pessoa, "Extraction of citronella (Cymbopogon nardus) essential oil using supercritical CO2: Experimental data and mathematical modeling," Brazilian J. Chem. Eng., vol. 28, no. 2, pp. 343-350, 2011.

[12] V. S. Mahalwal and M. Ali, "Volatile constituents of Cymbopogon nardus (Linn.) Rendle," Flavour and Fragrance Journal, vol. 18, no. 1. pp. 73-76, 2003.

[13] Y. Trongtokit, Y. Rongsriyam, N. Komalamisra, and C. Apiwathnasorn, "Comparative repellency of 38 essential oils against mosquito bites," Phyther. Res., vol. 19, no. 4, pp. 303-309, 2005.

[14] M. H. Hamzah, H. Che Man, Z. Z. Abidin, and H. Jamaludin, "Comparison of citronella oil extraction methods from Cymbopogon nardus grass by ohmic-heated hydro-distillation, hydrodistillation, and steam distillation," BioResources, vol. 9, no. 1. pp. 256-272, 2014.

[15] K. Nakahara, N. S. Alzoreky, T. Yoshihashi, H. T. T. Nguyen, and G. Trakoontivakorn, "Chemical Composition and Antifungal Activity of Essential Oil from Cymbopogon nardus (Citronella Grass)," Japan Agric. Res. Q., vol. 37, no. 4, pp. 249-252, 2003.

[16] Tajidin, N. E, "Chemical composition and citral content in lemongrass (Cymbopogon citratus) essential oil at three maturity stages," AFRICAN J. Biotechnol., vol. 11, no. 11, 2012.

[17] M. H. Hamzah et al., "Preliminary study of ohmic heated hydro distillation for essential oil's plant extraction," in Proceedings - 2011 IEEE Student Conference on Research and Development, SCOReD 2011, 2011, pp. 211-214.

[18] H. C. Man, M. H. Hamzah, H. Jamaludin, and Z. Z. Abidin, "Preliminary Study: Kinetics of Oil Extraction from Citronella Grass by Ohmic Heated Hydro Distillation," APCBEE Procedia, vol. 3, pp. 124-128, 2012.

[19] N. \& O. C. O.v, "Phytochemical constituents of some selected medicinal plants," in African Journal of Pure and Applied Chemistry, vol. 3, no. 11, 2009, pp. 228-233.

[20] B. Schaneberg and I. a Khan, "Comparison of Extraction Methods for Marker Compounds in the Essential oil of lemongrass by GC," J. Agric. Food Chem., vol. 50, no. 6, pp. 1345-1349, 2002.

[21] M. F. Asaolu, O. a. Oyeyemi, and J. O. Olanlokun, "Chemical Compositions, Phytochemical Constituents and in vitro Biological Activity of Various Extracts of Cymbopogon citratus," Pakistan J. Nutr., vol. 8, no. 12, pp. 1920-1922, 2009.

[22] M. Ranitha, A. H. Nour, A. S. Ziad, H. N. Azhari, and S. Thanaraj, "Optimization of Microwave Assisted Hydrodistillation of Lemongrass ( Cymbopogon Citratus ) Using Response Surface Methodology," Int. J. Res. Eng. Technol., vol. 3, no. 4, pp. 5-14, 2014.

[23] A. H. Nour, M. Ranitha, and A. H. Nour, "Extraction and Characterization of Essential Oil from from Ginger ( Zingiber Officinale Roscoe ) and Lemongrass ( Cymbopogon citratus ) by Microwave- Assisted Hydrodistillation," Int. J. Chem. Environ. Eng., vol. 4, no. 4, pp. 221-226, 2013.

[24] R. M., A. H. Nour, Z. A. Sulaiman, A. H. Nour, and T. R. S., "A Comparative Study of Lemongrass (Cymbopogon Citratus) Essential Oil Extracted by Microwave-Assisted Hydrodistillation (MAHD) and Conventional Hydrodistillation (HD) Method," Int. J. Chem. Eng. Appl., vol. 5, no. 2, pp. 104-108, 2014.

[25] M. Ranitha, A. H. Nour, Z. A. Sulaiman, A. H. Nour, and T. R. S, "Comparison of Chemical Composition and Toxicity of Essential Oils from Lemongrass (Cymbopogon Citratus) Extracted with Microwave-Assisted Hydrodistillation (MAHD) and Coventional Hydrodistillation (HD) Methods," J. Adv. Nat. Sci., vol. 1, no. 1, 2014.

[26] W. Boonyuan, J. P. Grieco, M. J. Bangs, A. Prabaripai, S. Tantakom, and T. Chareonviriyaphap, 
"Excito-repellency of essential oils against an Aedes aegypti (L.) field population in Thailand," $J$. Vector Ecol., vol. 39, no. 1, pp. 112-122, 2014.

[27] A. Wany, S. Jha, V. K. Nigam, and D. M. Pandey, "Chemical Analysis and Therapeutic Uses of Citronella Oil from Cymnopogon Winterianus: A Short Review," Int. J. Adv. Res., vol. 1, no. 6, pp. 504-521, 2013.

[28] N. Rani, A. Wany, A. S. Vidyarthi, and D. M. Pandey, "Study of Citronella leaf based herbal mosquito repellents using natural binders," Curr. Res. Microbiol. Biotechnol., vol. 1, no. 3, pp. 98-103, 2013.

[29] A. Wany, S. Jha, V. K. Nigam, and D. M. Pandey, "Chemical Analysis and Therapeutic Uses of Citronella Oil from Cymnopogon Winterianus: A Short Review," Int. J. Adv. Res., vol. 1, no. 6, pp. 504-521, 2013.

[30] A. R. Mohamed Hanaa, Y. I. Sallam, A. S. El-Leithy, and S. E. Aly, "Lemongrass (Cymbopogon citratus) essential oil as affected by drying methods," Ann. Agric. Sci., vol. 57, no. 2, pp. 113-116, 2012.

[31] T. Jumepaeng et al., "Determination and comparison of volatile aroma compounds in fresh and dried leaves samples of citronella grass, lemongrass, and citronella incense products by microhydrodistillation," Acta Chromatogr., vol. 26, no. 1, pp. 177-190, 2014.

[32] S. Chanthai, S. Prachakoll, C. Ruangviriyachai, and D. L. Luthria, "Influence of extraction methodologies on the analysis of five major volatile aromatic compounds of citronella grass (cymbopogon nardus) and lemongrass (cymbopogon citratus) grown in thailand," J. AOAC Int., vol. 95, no. 3, pp. 763-772, 2012.

[33] B. Prashant Tiwari, M. K. Kumar, and H. K. Gurpreet Kaur, "Phytochemical screening and extraction - A review," Int. Pharm. Sci., vol. 1, no. 1, pp. 98-106, 2011.

[34] H. K. Sandhar, B. Kumar, S. Prasher, P. Tiwari, M. Salhan, and P. Sharma, "A Review of Phytochemistry and Pharmacology of Flavonoids," Int. Pharm. Sci., vol. 1, no. 1, pp. 25-41, 2011.

[35] C. E. Ekpenyong and E. E. Akpan, "Use of Cymbopogon citratus essential oil in food preservation: Recent advances and future perspectives," Crit. Rev. Food Sci. Nutr., vol. 57, no. 12, pp. 2541-2559, 2017.

[36] T. Arif et al., "Natural products--antifungal agents derived from plants.," J. Asian Nat. Prod. Res., vol. 11, no. February 2015, pp. 621-638, 2009.

[37] W. S. Hsu, J. H. Yen, and Y. S. Wang, "Formulas of components of citronella oil against mosquitoes (Aedes aegypti)," J. Environ. Sci. Heal. - Part B Pestic. Food Contam. Agric. Wastes, vol. 48, no. 11, pp. 1014-1019, 2013.

[38] "Biological activity of Cymbopogon schoenanthus essential oil," Saudi J. Biol. Sci., vol. 24, no. 7, pp. 1458-1464, Nov. 2017.

[39] A. Godwin et al., "Determination of elemental, phenolic, antioxidant and flavonoid properties of Lemon grass (Cymbopogon citratus Stapf)," Int. Food Res. J., vol. 21, no. 5, pp. 1971-1979, 2014.

[40] S. F. Soares et al., "Repellent activity of plant-derived compounds against Amblyomma cajennense (Acari: Ixodidae) nymphs," Vet. Parasitol., vol. 167, no. 1, pp. 67-73, 2010.

[41] M. O. Soares et al., "Evaluation of antioxidant and antimicrobial properties of the Angolan Cymbopogon Citratus essential oil with a view to Its utilization as food biopreservative," J. Agric. Sci., vol. 5, no. 7, pp. 36-45, 2013.

[42] M. O. Soares, R. C. Alves, P. C. Pires, M. B. P. P. Oliveira, and A. F. Vinha, "Angolan Cymbopogon citratus used for therapeutic benefits: Nutritional composition and influence of solvents in phytochemicals content and antioxidant activity of leaf extracts," Food Chem. Toxicol., vol. 60, pp. 413-418, 2013.

[43] "Data showing chemical compositions of the essential oils of the leaves of Cymbopogon citratus obtained by varying pH of the extraction medium," Data Br., vol. 8, pp. 599-604, Sep. 2016.

[44] E. O. Ajayi, A. P. Sadimenko, and A. J. Afolayan, "GC-MS evaluation of Cymbopogon citratus (DC) Stapf oil obtained using modified hydrodistillation and microwave extraction methods," Food Chem., vol. 209, pp. 262-266, 2016. 
[45] E. O. Ajayi, A. P. Sadimenko, and A. J. Afolayan, "Data showing chemical compositions of the essential oils of the leaves of Cymbopogon citratus obtained by varying $\mathrm{pH}$ of the extraction medium," Data Br., vol. 8, pp. 599-604, 2016.

[46] M. E. Lucchesi, F. Chemat, and J. Smadja, "Solvent-free microwave extraction of essential oil from aromatic herbs: Comparison with conventional hydro-distillation," J. Chromatogr. A, vol. 1043, no. 2, pp. 323-327, 2004.

[47] A. Filly, X. Fernandez, M. Minuti, F. Visinoni, G. Cravotto, and F. Chemat, "Solvent-free microwave extraction of essential oil from aromatic herbs: From laboratory to pilot and industrial scale," Food Chem., vol. 150, pp. 193-198, 2014.

[48] M. T. Golmakani and K. Rezaei, "Comparison of microwave-assisted hydrodistillation withthe traditional hydrodistillation method in the extractionof essential oils from Thymus vulgaris L.," Food Chem., vol. 109, no. 4, pp. 925-930, 2008.

[49] "GC-MS evaluation of Cymbopogon citratus (DC) Stapf oil obtained using modified hydrodistillation and microwave extraction methods," Food Chem., vol. 209, pp. 262-266, Oct. 2016.

[50] M. R. Thakker, J. K. Parikh, and M. A. Desai, "Microwave assisted extraction of essential oil from the leaves of Palmarosa: Multi-response optimization and predictive modelling," Ind. Crops Prod., vol. 86, 2016.

[51] L. Cervantes-Ceballos, K. Caballero-Gallardo, and J. Olivero-Verbel, "Repellent and Anti-quorum Sensing Activity of Six Aromatic Plants Occurring in Colombia.," Nat. Prod. Commun., vol. 10, no. 10, pp. 1753-1757, 2015.

[52] H. K. P. Ha, J. Maridable, P. Gaspillo, M. Hasika, R. Malaluan, and J. Kawasaki, "Essential oil from lemongrass extracted by supercritical carbon dioxide and steam distillation," Philipp. Agric. Sci., vol. 91, no. 1, pp. 36-41, 2008.

[53] L. H. C. Carlson, R. A. F. Machado, C. B. Spricigo, L. K. Pereira, and A. Bolzan, "Extraction of lemongrass essential oil with dense carbon dioxide," J. Supercrit. Fluids, vol. 21, no. 1, pp. 33-39, 2001.

[54] R. Timung, C. R. Barik, S. Purohit, and V. V. Goud, "Composition and anti-bacterial activity analysis of citronella oil obtained by hydrodistillation: Process optimization study," Ind. Crops Prod., vol. 94, 2016.

[55] R. Timung, C. R. Barik, S. Purohit, and V. V. Goud, "Composition and anti-bacterial activity analysis of citronella oil obtained by hydrodistillation: Process optimization study," Ind. Crops Prod., vol. 94, pp. 178-188, 2016.

[56] V. K. Koul, B. M. Gandotra, S. Koul, S. Ghosh, C. L. Tikoo, and A. K. Gupta, "Steam distillation of lemon grass (Cymbopogon spp.)," Indian J. Chem. Technol., vol. 11, no. 1, pp. 135-139, 2004.

[57] E. Cassel, R. M. F. Vargas, N. Martinez, D. Lorenzo, and E. Dellacassa, "Steam distillation modeling for essential oil extraction process," Ind. Crops Prod., vol. 29, no. 1, pp. 171-176, 2009.

[58] E. Cassel, R. M. F. Vargas, and P. J. Nathan, "Experiments and Modeling of the Cymbopogon winterianus Essential Oil Extraction by Steam Distillation," Chem. Soc, vol. 50, no. 3, pp. 126129, 2006.

[59] G. O. Onawunmi, W. A. Yisak, and E. O. Ogunlana, "Antibacterial constituents in the essential oil of Cymbopogon citratus (DC.) Stapf.," J. Ethnopharmacol., vol. 12, no. 3, pp. 279-286, 1984.

[60] B. T. Schaneberg and I. A. Khan, "Comparison of extraction methods for marker compounds in the essential oil of lemon grass by GC," J. Agric. Food Chem., vol. 50, no. 6, pp. 1345-1349, 2002.

[61] L. S. Chagonda, C. Makanda, and J.-C. Chalchat, "Essential oils of cultivated cymbopogon winterianus (Jowitt) and of C. citratus (DC) (Stapf) from Zimbabwe," J. Essent. Oil Res., vol. 12, no. 4, pp. 478-480, 2000.

[62] L. S. Wei and W. Wee, "Chemical composition and antimicrobial activity of Cymbopogon nardus citronella essential oil against systemic bacteria of aquatic animals," Iran. J. Microbiol., vol. 5, no. 2, pp. 147-152, 2013. 
[63] A. J. "ANGIOSTRONGYLUS-V. I. D. I. W. . V. R. 120. 1. (1987): 424-424. Trees, "Characterization and phytotoxicity studes of suspended particulate matter (SPM) in Chennai urban area," Profesional Psychology. 1987.

[64] P. subramanian; che wan imanina; che wan takwa; nurul Emelia, "Chemical composition and antibacterial activity of essential oil of Cymbopogon citratus and Cymbopogon nardus against Enterococcus faecalis.” p. vol.6, no. 9, pp. 9-17, 2015.

[65] G. S. . Viana, T. . Vale, R. S. . Pinho, and F. J. . Matos, "Antinociceptive effect of the essential oil from Cymbopogon citratus in mice," J. Ethnopharmacol., vol. 70, no. 3, pp. 323-327, 2000.

[66] C. K. Kokate, R. E. Rao, and K. C. Varma, "Pharmacological investigations of essential oil of Cymbopogon nardus (L.) Rendle: studies on central nervous system.," Indian J. Exp. Biol., vol. 9, no. 4, pp. 515-516, 1971.

[67] G. T. S, "ANTIOXIDANT PROFILES OF CYMBOPOGAN CITRATUS (DC) STAPF. LEAVES,” Int. J. Pharm. Sci. Bus. Manag., vol. 4, no. 1, pp. 1-12, 2016.

[68] T. S. Geetha and N. Geetha, "Phytochemical screening, quantitative analysis of primary and secondary metabolites of Cymbopogan citratus (DC) stapf. Leaves from Kodaikanal hills, Tamilnadu," Int. J. PharmTech Res., vol. 6, no. 2, pp. 521-529, 2014.

[69] V. Nambiar and H. Matela, "Potential functions of Lemon grass (Cymbopogon citratus) in health and disease," Int. J. Pharm. Biol. Arch., vol. 3, no. 5, pp. 1035-1043, 2012.

[70] K. S. Banu and L. Cathrine, "General Techniques Involved in Phytochemical Analysis," Int. J. Adv. Res. Chem. Sci., vol. 2, no. 4, pp. 25-32, 2015.

[71] A. J. Uraku et al., "Nutritional and Anti-Nutritional Quantification Assessment of Cymbopopgon citratus Leaf," Pharmacol. Pharm., vol. 6, no. August, pp. 401-410, 2015.

[72] S. N. Baharum, H. Bunawan, M. A. Ghani, Wan Aida Wan Mustapha, and N. M. Noor, "Analysis of the chemical composition of the essential oil of Polygonum minus Huds. Using twodimensional gas chromatography-time-of-flight mass spectrometry (GC-TOF MS)," Molecules, vol. 15 , no. 10, pp. 7006-7015, 2010.

[73] A. Al-Harrasi and S. Al-Saidi, "Phytochemical analysis of the essential oil from botanically certified oleogum resin of Boswellia sacra (Omani luban)," Molecules, vol. 13, no. 9, pp. 21812189, 2008.

[74] X. Ling and W. Bochu, "A review of phytotherapy of gout: Perspective of new pharmacological treatments," Pharmazie, vol. 69, no. 4. pp. 243-256, 2014.

[75] A. M. Guiotti et al., "Antimicrobial activity of conventional and plant-extract disinfectant solutions on microbial biofilms on a maxillofacial polymer surface," J. Prosthet. Dent., vol. 116, no. 1, pp. 136-143, 2016.

[76] D. Ganjewala, "Cymbopogon essential oils : Chemical compositions and bioactivities," Int. J. Essent. Oil Ther., vol. 3, no. APRIL 2009, pp. 56-65, 2009.

[77] O. Avoseh, O. Oyedeji, P. Rungqu, B. Nkeh-Chungag, and A. Oyedeji, "Cymbopogon species; ethnopharmacology, phytochemistry and the pharmacological importance," Molecules, vol. 20, no. 5, pp. 7438-7453, 2015.

[78] T. T. Kahsay, G. / Medhin, and G. / Mariam, "Antimicrobial, Antioxidant and Anthelmintic Activities of the Essential Oils and methanol Extract of Cymbopogon Citratus," Int. J. Mod. Chem. Appl. Sci., vol. 3, no. 3, pp. 433-436, 2016.

[79] H. Marican, R. Edros, M. Mohammad, and S. Salleh, "Antimicrobial activity of tropical soft corals found in the Northern Straits of Malacca," Int. J. Eng. Technol. Sci., vol. 6, no. 1, pp. 1-10, 2016.

[80] P. Phuneerub, C. Palanuvej, and N. Ruangrungsi, "Pharmacognostic specification, mutagenic and antimutagenic properties of Cymbopogon nardus roots in Thailand," J. Chem. Pharm. Res., vol. 6, no. 9, pp. 389-396, 2014.

[81] Usanee Vinitketkumnuen, Rawiwan Puatanachokchai, Prachya Kongtawelert, Nirush Lertprasertsuke, and Taijiro Matsushima, "Antimutagenicity of lemon grass (Cymbopogon citratus Stapf) to various known mutagens in salmonella mutation assay," Mutat. Res. Toxicol., vol. 341, no. 1, pp. 71-75, 1994. 
[82] O. A. Lawal, A. L. Ogundajo, N. O. Avoseh, and I. A. Ogunwande, "Cymbopogon citratus," in Medicinal Spices and Vegetables from Africa, 2017, pp. 397-423.

[83] J. D. Gbenou et al., "Phytochemical composition of Cymbopogon citratus and Eucalyptus citriodora essential oils and their anti-inflammatory and analgesic properties on Wistar rats," Mol. Biol. Rep., vol. 40, no. 2, pp. 1127-1134, 2013.

[84] J. Sagradas et al., "Gastroprotective effect of Cymbopogon citratus infusion on acute ethanolinduced gastric lesions in rats," J. Ethnopharmacol., vol. 173, pp. 134-138, 2015.

[85] C. A. R. A. Costa, L. T. Bidinotto, R. K. Takahira, D. M. F. Salvadori, L. F. Barbisan, and M. Costa, "Cholesterol reduction and lack of genotoxic or toxic effects in mice after repeated 21-day oral intake of lemongrass (Cymbopogon citratus) essential oil," Food Chem. Toxicol., vol. 49, no. 9, pp. 2268-2272, 2011.

[86] T. S., W. R., and K. N., "Antimicrobial constituents and synergism effect of the essential oils from Cymbopogon citratus and Alpinia galanga," Nat. Prod. Commun., vol. 9, no. 2, pp. 277-280, 2014.

[87] R. W. D. S. Aguiar, M. A. Ootani, S. D. Ascencio, T. P. S. Ferreira, M. M. Dos Santos, and G. R. Dos Santos, "Fumigant antifungal activity of corymbia citriodora and Cymbopogon nardus essential oils and citronellal against three fungal species," Sci. World J., vol. 2014, 2014.

[88] M. A. Clemente, C. M. De Oliveira Monteiro, M. G. Scoralik, F. T. Gomes, M. C. De Azevedo Prata, and E. Daemon, "Acaricidal activity of the essential oils from Eucalyptus citriodora and Cymbopogon nardus on larvae of Amblyomma cajennense (Acari: Ixodidae) and Anocentor nitens (Acari: Ixodidae)," Parasitol. Res., vol. 107, no. 4, pp. 987-992, 2010.

[89] P. Singh, R. Shukla, A. Kumar, B. Prakash, S. Singh, and N. K. Dubey, "Effect of Citrus reticulata and Cymbopogon citratus essential oils on Aspergillus flavus growth and aflatoxin production on Asparagus racemosus," Mycopathologia, vol. 170, no. 3, pp. 195-202, 2010.

[90] T. Arif et al., "Natural products - Antifungal agents derived from plants," Journal of Asian Natural Products Research, vol. 11, no. 7. pp. 621-638, 2009. 